\title{
PARTY SYSTEM OF UKRAINE: CHARACTERISTICS OF THE MAIN PERIODS OF DEVELOPMENT (1991-2019)
}

\author{
Ostapets Yu. O.
}

\section{INTRODUCTION}

A modern democratic state is impossible without political parties, which are important elements of a democratic political system. In transitionsocieties the party system can even be called an indicator of democratization. The establishment of consolidated democracy also depends on the consolidation of the party system.

However, the formation of party systems is a complex process that depends on many factors and the specific historical conditions in which it takes place. Studying the experience of forming party systems in states where political democracy is just emerging is necessary for a theoretical understanding of the general patterns and socio-cultural features of the evolution of party systems. The understanding of such experience is necessary while studying the peculiarities of domestic party systemfunctioning.

The research is also updated by the fact that Ukrainian partogenesis requires its own research methodology, which would be formed taking into account the achievements of foreign political science, as well as the domestic experience of party formation. Therefore, there is an urgent need for new content, the reconceptualization of terms and categories that are used to analyze the party system of Ukraine. The problems of peroidization of the party system development also belong to disputable issues of modern science.

\section{Research methodology and empirical indicators of party system development in Ukraine}

Political science has a commonly accepted methodology to analyze the evolution of party systems in transitional societies, Ukraine included. Firstly, their functioning is preconditioned by a process of historical institutionalization. Political parties having emerged in new democratic societies usually function according to inclusive, cartel, and postmaterial values parties ${ }^{1}$. Secondly, the logic of their development is subordinated to the logic of democratic transition. In doing so, the researchers identify the following possible models of democratic transition: 1) successful transition; 2) the returning to the postauthoritarian regime; 3 ) interrupted transition (such states are referred to in a

1 Остапець Ю. Еволюція партійної системи України в умовах трансформації соціальних і політичних структур / Ужгород: ЗІППО, 2016. 252 с. 
different way, and namely: "pseudodemocracy", "delegative democracy", "bureaucratic patrimonialism", "hybrid state" etc.). Thirdly, the formation of the Ukrainian party system takes place within the context of interrupted transition. Successful transition to democracy is linked to the consolidation of party systems. A. Shherbak and H. Holosov argue that such a consolidation is associated with a decrease in party fragmentation (measured by the index of the effective number of parties) and electoral volatility (Pedersen's index $)^{2}$.

In our opinion, an index of nationalization of the party system, favoring the assessment of its regional development should be added to the empirical indicators of consolidation. The calculation of these indices for the Ukrainian party system is presented in Table 1.

Table 1

Empirical Indices of Party System Development in Ukraine (1998-2019)

\begin{tabular}{|c|c|c|c|c|c|c|c|}
\hline Indices & $\mathbf{1 9 9 8}$ & $\mathbf{2 0 0 2}$ & $\mathbf{2 0 0 6}$ & $\mathbf{2 0 0 7}$ & $\mathbf{2 0 1 2}$ & $\mathbf{2 0 1 4}$ & $\mathbf{2 0 1 9}$ \\
\hline ENPS & 4,9 & 4,7 & 3.4 & 3,3 & 4,3 & 4,8 & 2,7 \\
\hline ENPV & 9,0 & 6,9 & 5,2 & 3,8 & 4,9 & 7,5 & 4,4 \\
\hline IPed & - & 46 & 50 & 17 & 36 & 61 & 69 \\
\hline PSNS & 0,65 & 0,62 & 0,66 & 0,68 & 0,72 & 0,76 & 0,74 \\
\hline
\end{tabular}

The regional configuration of the party system of Ukraine is characterized within the framework of the theory of nationalization of political parties and party systems. According to $\mathrm{H}$. Holosov, the process of nationalization of party systems means the unification of electoral support of political parties in different territorial units of the state. The party system is fully nationalized when the proportions of votes received by the parties in different territorial units of the state are the same. If parties get electoral support only in some regions, the party system is considered to be nationalized ${ }^{3}$.

Since political science does not have a unified approach to the study of territorial homogeneity of electoral preferences, we will use the Index of Political Party Nationalization (PNS) and of Party Systems (PSNS), elaborated by $\mathrm{M}$. Jones and S. Meinvering. It has been successfully tested on electoral data $^{4}$. The results of calculating the nationalization index for the parliamentary parties of Ukraine are presented in Table 2.

2 Голосов Г. Фрагментация партийных систем: новый метод измерения и его применеие к результатам выборов российских региональных законодательных собраний (2003-2008). Электоральное пространство современной России. Политическая наука: Ежегодник 2008. М.: РОССПЭН, 2009. С. 9-27.

3 Голосов Г. Национализация партийной системы: российская специфика. Политическая наука. 2015. № 1. С. 128-156.

4 Туровский Р. Национализация и регионализация партийных систем: подходы к исследованию / Р. Туровский. Полития. 2016. № 1. С. 162-180. 
Table 2

Index of Nationalization of Parliamentary Parties According to the Results of elections to Verkhovna Rada (1998-2019)

\begin{tabular}{|c|c|c|c|c|c|c|}
\hline Parties / Election Blocs* & 1998 & 2002 & 2006 & 2012 & 2014 & 2019 \\
\hline 1 & 2 & 3 & 4 & 5 & 6 & 7 \\
\hline Narodnyj Rukh Ukrajiny & 0,561 & & & & & \\
\hline Partija Zelenykh Ukrajiny & 0,855 & & & & & \\
\hline $\begin{array}{l}\text { "Social Party of Ukraine } \\
\text { and the Peasant Party of } \\
\text { Ukraine" election bloc }\end{array}$ & 0,525 & & & & & \\
\hline $\begin{array}{l}\text { Communist Party of } \\
\text { Ukraine }\end{array}$ & 0,705 & 0,644 & 0,725 & 0,668 & & \\
\hline $\begin{array}{l}\text { All-Ukrainian unity } \\
\text { "Ghromada" }\end{array}$ & 0,515 & & & & & \\
\hline $\begin{array}{l}\text { Progressive Socialist Party } \\
\text { of Ukraine }\end{array}$ & 0,554 & & & & & \\
\hline $\begin{array}{l}\text { Social Democratic Party of } \\
\text { Ukraine (united) }\end{array}$ & 0,597 & 0,666 & & & & \\
\hline National Democratic Party & 0,811 & & & & & \\
\hline $\begin{array}{l}\text { "National Front" } \\
\text { Election Bloc }\end{array}$ & 0,281 & & & & & \\
\hline $\begin{array}{l}\text { Viktor Jushhenko's “Our } \\
\text { Ukraine”Election Block }\end{array}$ & & 0,553 & 0,603 & & & \\
\hline $\begin{array}{l}\text { "Za Jedynu Ukrajinu" } \\
\text { Election Bloc }\end{array}$ & & 0,681 & & & & \\
\hline $\begin{array}{l}\text { Julija Tymoshenko ‘s } \\
\text { Election Blok / } \\
\text { All-Ukrainian Unity } \\
\text { "Batjkivshhyna" *** }\end{array}$ & & 0,639 & 0,705 & 0,761 & 0,846 & 0,77 \\
\hline Socialist Party of Ukraine & & 0,514 & 0,633 & & & \\
\hline Party of Regions & & & 0,541 & 0,685 & & \\
\hline Political Party "Udar" & & & & 0,828 & & \\
\hline $\begin{array}{l}\text { All-Ukrainian Unity } \\
\text { "Svoboda" }\end{array}$ & & & & 0,534 & & 0,55 \\
\hline $\begin{array}{l}\text { Political Party } \\
\text { "People "s Front" }\end{array}$ & & & & & 0,754 & \\
\hline $\begin{array}{l}\text { Political Party "Petro } \\
\text { Poroshenko's bloc" / } \\
\text { Political Party "European } \\
\text { Solidarity" **** }\end{array}$ & & & & & 0,891 & 0,73 \\
\hline
\end{tabular}


Table 2 (continued)

\begin{tabular}{|c|c|c|c|c|c|c|}
\hline 1 & 2 & 3 & 4 & 5 & 6 & 7 \\
\hline $\begin{array}{l}\text { Political Party } \\
\text { "Samopomich Union" }\end{array}$ & & & & & 0,804 & 0,57 \\
\hline $\begin{array}{l}\text { Political Party } \\
\text { "Opposition bloc" }\end{array}$ & & & & & 0,418 & 0,56 \\
\hline $\begin{array}{l}\text { Oleh Ljashko’s } \\
\text { Radical Party }\end{array}$ & & & & & 0,805 & 0,71 \\
\hline $\begin{array}{l}\text { Political Party } \\
\text { "People's Servant" }\end{array}$ & & & & & & 0,89 \\
\hline $\begin{array}{l}\text { Political Party } \\
\text { "Opposition Platform - } \\
\text { For Life" }\end{array}$ & & & & & & 0,55 \\
\hline $\begin{array}{l}\Pi \text { «Голос» } \\
\text { Political Party "Voice" }\end{array}$ & & & & & & 0,58 \\
\hline $\begin{array}{l}\text { Nationalization } \\
\text { of the Party System } \\
\text { of Ukraine }\end{array}$ & 0,64 & 0,62 & 0,66 & 0,72 & 0,76 & 0,74 \\
\hline
\end{tabular}

*Beginning with 2012 parliamentary elections, election blocs don't participate in the elections.

**In 2006 "Our Ukraine" election block.

*** In 2012, 2014, 2019 - "Batjkivshhyna" election bloc.

**** In 2019 p. - political party "European Solidarity".

To characterize the peculiarities of the development of the party system of Ukraine, we suggest to consider the stages of its evolution within the context of our study. The key points of the periodization is the accentuation of the periods based on the so-called major electoral cycles, including parliamentary, presidential and local elections. As the starting point of such an electoral cycle, the next parliamentary elections should be considered. But taking into consideration the status of the President of Ukraine in the system of state power, the scope of his power and the mechanisms of influence on the internal politics of the state, presidential elections might be considered as the starting point of the electoral cycle. According to the results of 2004, 2010, 2014 presidential elections, the form of the government was changed, and new party structures, dominating Ukrainian politics for a period of time, were formed.

The changes in the content structure and the form of the government might be attributed to the criteria of period accentuation. So, period division looks like this: the first period lasts from 1991 to 2004, the second - from 2004 to 2014, the third from 2014 to 2019 , and the fourth starts in 2019. It should be noted that in 2010 there was a change in the form of the government, however 
we do not single out a new period in the development of the party system, since there were no significant changes in its structure.

The main factors influencing the evolution of the party system are the following: electoral processes; features of democratic transit (hybrid political regime); socio-political distinctions; the institutional environment (presidentialism, the lack of proper regulatory framework, constant changes in the electoral system, etc.); constitutional volatility (changing the form of government in 2004, 2010, 2014); traditions of clientelism, paternalism, regionalism; regionalization of party influence and the emergence of regional parties.

\section{Development of the party system of Ukraine during 1991-2019}

The first period (1991-2004) in the development of the party system was characterized by the opposition of independence supporters and proWestern foreign policy orientation with the supporters of the idea of preserving the former USSR and reintegration within its borders.

Presidential, parliamentary and local elections had a decisive influence on both the national and regional configuration of the party system. Attention should be paid to "constituent elections", to which we attribute 1990, 1994 elections to Verkhovna Rada of Ukraine and 1991 and 1994 presidential elections.

The analysis of their results shows that their impact on political processes in Ukraine was ambivalent. On the one hand, the constituent elections successfully fulfilled their functions within the period of a democratic transition: they established an institutional design within which both electoral competition and party system evolve; created the models of electoral behavior of the population, having a pronounced regional character; created the basis for legitimizing the future political regime ${ }^{5}$. On the other hand, they contributed to the establishment of a hybrid political regime in Ukraine.

The results of the parliamentary elections during 1998-2019 (party winners listed on the party lists) are presented in Table 3 . The table does not indicate the results of the 2007 snap elections since they did not have a significant impact on the configuration of the party system.

A characteristic feature of 1998 parliamentary elections was the emergence of the phenomenon of political parties of one region. Voting for such parties was fixed in Transcarpathian (Social Democratic Party of Ukraine (United) - 31, 17\%), Dnipropetrovsk (all-Ukrainian Union "Ghromada"$35,34 \%$ ) and Sumy ("Progressive Socialist Party of Ukraine" - 20,89\%)

5 Манайло-Приходько Р. Вплив «установчих» виборів на еволюцію партійної системиУкраїни. Гілея: науковий вісник. Збірник наукових праџь. К.: «Видавництво «Гілея», 2018. Випуск 135. С. 362-367. 
regions. Due to such voting, these parties overcame the $4 \%$ barrier of voters in Ukraine 6 .

Table 3

Results of the Elections to Verkhovna Rada of Ukraine in 1998- 2019

\begin{tabular}{|c|c|c|c|c|c|c|}
\hline Parties / Election Blocs* & $\begin{array}{c}1998, \\
\%\end{array}$ & $\begin{array}{c}2002, \\
\%\end{array}$ & $\begin{array}{l}2006, \\
\%\end{array}$ & $\begin{array}{c}2012, \\
\%\end{array}$ & $\begin{array}{c}2014, \\
\%\end{array}$ & $\begin{array}{c}2019, \\
\%\end{array}$ \\
\hline 1 & 2 & 3 & 4 & 5 & 6 & 7 \\
\hline Narodnyj Rukh Ukrajiny & 9,4 & & & & & \\
\hline Partija Zelenykh Ukrajiny & 5,43 & & & & & \\
\hline $\begin{array}{l}\text { "Social Party of Ukraine } \\
\text { and the Peasant Party of } \\
\text { Ukraine" election bloc }\end{array}$ & 8,55 & & & & & \\
\hline $\begin{array}{l}\text { Communist Party of } \\
\text { Ukraine }\end{array}$ & 24,65 & 19,98 & 3,66 & 13,18 & & \\
\hline $\begin{array}{l}\text { All-Ukrainian unity } \\
\text { "Ghromada" }\end{array}$ & 4,67 & & & & & \\
\hline $\begin{array}{l}\text { Progressive Socialist Party } \\
\text { of Ukraine }\end{array}$ & 4,04 & & & & & \\
\hline $\begin{array}{l}\text { Social Democratic Party of } \\
\text { Ukraine (united) }\end{array}$ & 4,01 & 6,27 & & & & \\
\hline National Democratic Party & 5,01 & & & & & \\
\hline $\begin{array}{l}\text { Viktor Jushhenko's “Our } \\
\text { Ukraine”Election Block }\end{array}$ & & 23,57 & 13,95 & & & \\
\hline $\begin{array}{l}\text { "Za Jedynu Ukrajinu" } \\
\text { Election Bloc }\end{array}$ & & 11,77 & & & & \\
\hline $\begin{array}{l}\text { Julija Tymoshenko ‘s } \\
\text { Election Bloc / } \\
\text { All-Ukrainian Unity } \\
\text { "Batjkivshhyna" *** }\end{array}$ & & 7,26 & 22,29 & 25,24 & 5,68 & 8,18 \\
\hline Socialist Party of Ukraine & & 6,87 & 5,69 & & & \\
\hline Party of Regions & & & 32,14 & 30,0 & & \\
\hline Political Party "Udar" & & & & 13,96 & & \\
\hline $\begin{array}{l}\text { All-Ukrainian Unity } \\
\text { "Svoboda" }\end{array}$ & & & & 10,44 & & \\
\hline
\end{tabular}

6 Остапець Ю. Електоральні процеси в Україні: загальнонаціональний та регіональний виміри. Дисертація на здобуття наукового ступеня доктора політичних наук (23.00.02 - політичні інститути і процеси). Львів, 2016. 550 c. URL: http://www.lnu.edu.ua/wpcontent/uploads/2016/11/dis_ostapets.pdf 
Table 3 (continued)

\begin{tabular}{|c|c|c|c|c|c|c|}
\hline 1 & 2 & 3 & 4 & 5 & 6 & 7 \\
\hline $\begin{array}{l}\text { Political Party } \\
\text { "People "s Front" }\end{array}$ & & & & & 22,14 & \\
\hline $\begin{array}{l}\text { Political Party "Petro } \\
\text { Poroshenko's bloc" / } \\
\text { Political Party "European } \\
\text { Solidarity" **** }\end{array}$ & & & & & 21,82 & 8,10 \\
\hline $\begin{array}{l}\text { Political Party } \\
\text { "Samopomich Union" }\end{array}$ & & & & & 10,97 & \\
\hline $\begin{array}{l}\text { Political Party } \\
\text { "Opposition bloc" }\end{array}$ & & & & & 9,43 & \\
\hline $\begin{array}{l}\text { Oleh Ljashko's } \\
\text { Radical Party }\end{array}$ & & & & & 7,44 & \\
\hline $\begin{array}{l}\text { Political Party } \\
\text { "People's Servant" }\end{array}$ & & & & & & 43,16 \\
\hline $\begin{array}{l}\text { Political Party "Opposition } \\
\text { Platform - For Life" }\end{array}$ & & & & & & 13,05 \\
\hline $\begin{array}{l}\Pi \text { «Голос» } \\
\text { Political Party "Voice" }\end{array}$ & & & & & & 5,82 \\
\hline
\end{tabular}

*Beginning with 2012 parliamentary elections, election blocs don't participate in the elections.

**In 2006 "Our Ukraine" election block.

*** In 2012, 2014, 2019 - "Batjkivshhyna" election bloc.

**** In 2019 p. - political party "European Solidarity".

The 2002 parliamentary elections became a point of bifurcation in the development of the party system. If, before 2002, its socio-economic and ideological demarcation had a dominant influence on its evolution, then after the elections it became a socio-cultural one. Accordingly, in the Western and Central regions the victory was gained by the Opposition Victor Yushchenko's bloc "Our Ukraine", which was based on political parties of nationaldemocratic orientation, and in the South and East, by the pro-government bloc "For a United Ukraine!" being formed by the centrist parties ${ }^{7}$.

Updating the socio-cultural division has "simplified" the task of the political forces in the next election campaigns. It was used in their election messages by both national democrats and their opponents (communist, centrist parties). The purpose of consolidation of the electorate was achieved through

${ }^{7}$ Трансформація партійної системи: український досвід у європейському контексті / За ред. Ю. Якименка. Київ: Центр Разумкова, 2017. С. 76. 
the appeal to issues on which the residents of different regions had different views (language, cultural values, foreign policy priorities). So, if before 2004 presidential election the socio-cultural division was reflected in the election results (parliamentary and presidential, being one of the factors influencing the structure of the party system, then during the 2004 election campaign it became a major factor influencing its configuration ${ }^{8}$. In addition, the specificity of the parliamentary elections was the structuring of the main subjects of the electoral process in the form of party blocs, which led to the loss of their recognition, their "dissolution" in the election blocs, and eventually to oblivion.

The second period (2004-2014) was characterized by socio-cultural confrontation along the East-West axis. Its peculiarity is manifested in the stability of the electoral map, which emerged as a result of 2004 presidential election and then was reflected in 2006, 2007, 2012 and 2010 parliamentary elections. The 2004 presidential election had a decisive influence on the configuration of Ukraine's party space. Firstly, the election resulted in the emergence of two electoral parts of Ukraine - Eastern and Western, being completely opposite: V. Yushchenko won in 17 regions (West, Center), and V. Yanukovych - in 10 regions (East, South). Secondly, the implementation of political reform (the law of December 8, 2004) meant holding parliamentary and local elections in a proportional system, and consequently an institutional strengthening of the status of political parties ${ }^{9}$. Accordingly, in 2006 elections to the Verkhovna Rada of Ukraine, the first place was won by Julija Tymoshenko "s election bloc and "Our Ukraine", in the regions where Viktor Yushchenko won, and in the regions where Viktor Yanukovych won, the first place was won by the "Party of Regions".

It should be noted that the results of 2006 and 2010 local elections point to the emergence of powerful regional parties in Ukraine. The main reasons for the emergence of regional political parties in Ukraine are: socio-cultural EastWest demarcation; ethno-linguistic difference and compact residence of national minorities in a certain territory (e.g. Hungarian minority in Transcarpathian region); timing of local and parliamentary elections (since 2010 local elections have been held separately from parliamentary ones); the regulatory and legal basis of the activities of political parties; reform of power decentralization and the formation of united territorial communities; the desire of regional elites to maintain influence and control over local resources; personal factor; administrative resource.

\footnotetext{
${ }^{8}$ Трансформація партійної системи: український досвід у європейському контексті / За ред. Ю. Якименка. Київ: Центр Разумкова, 2017. 428 с.

9 Остапець Ю. Еволюція партійної системи України в умовах трансформації соціальних і політичних структур/ Ужгород: ЗІППО, 2016. С. 136.
} 
The 2010 presidential election, which began a new electoral cycle, became a kind of continuation of the 2004 election, as it was held in opposition between political candidates from the East and the West of Ukraine. As in 2004, most of the western and central regions voted in favor of Yulia Tymoshenko ("Batjkivshhyna"), while the eastern and southern regions voted in favor of V. Yanukovych ("Party of Regions").

After the elections, deputies from the "Party of Regions" initiated the amendments to the Constitution of Ukraine, and on October 1, 2010 the Constitutional Court of Ukraine declared that the Law on Amendments to the Constitution of Ukraine of December 8, 2004, did not correspond to the Constitution of Ukraine due to the violation of the procedure of its consideration and adoption. The result was a return to the Constitution of 1996, and hence to a presidential-parliamentary form of government ${ }^{10}$.

So, if, following the results of 2010 local elections, the party system of Ukraine receives the format of a system with a dominant party of dominance, then by the results of 2012 parliamentary elections, it becomes two-pronged; the "Party of Regions", and the Communist party on the one hand, and allUkrainian unities "Batjkivshyna", "Svoboda" and the political party "Udar" on the other hand.

The third period (2014-2019) in the development of Ukraine's party system begins with a change in the electoral space structure (the victory of proEuropean-oriented political parties in most regions of Ukraine), the emergence of new political parties connected with the early presidential and 2014 parliamentary elections, changing the form of government (returning to the parliamentary-presidential one).

The early 2014 elections to the Verkhovna Rada of Ukraine changed dramatically the format of the party system and its structure. As a result of the elections, 4 new political parties were initiated into the Ukrainian Parliament: political party "People's Front", political party "Petro Poroshenko's Bloc", political party "Opposition Bloc", political party "Samopomich Union", Oleg Lyashko's Radical Party. From the previous composition of the Verkhovna Rada, only "Batkivshchyna" passed the barrier with the lowest result". The changes that have taken place in the composition structure of the party system make it possible to call it "the second Ukrainian party system". The first one was formed within 1991-2012.

The 2015 local council elections completed the "revolutionary electoral cycle" and finally confirmed the configuration of the party system.

10 Остапець Ю. Еволюція партійної системи України в умовах трансформації соціальних і політичних структур/ Ужгород: ЗІППО, 2016. С. 167.

${ }^{11}$ Партійна система України до і після Майдану: зміни, тенденції розвитку, суспільні запити. Національна безпека і оборона України. 2015. № 6-7. 18. С. 134. 
A characteristic feature of elections is the participation of a large number of regional and sub-regional parties. For example, political party "Sergiy Kaplin's Party of Ordinary People" in Poltava, political party "All-Ukrainian union "Cherkashhyna" in Cherkasy region, political party "Trust the affairs" in Odessa, political party "United Center", "KMKS - Party of the Hungarians of Ukraine, the "Democratic Party of Hungarians of Ukraine) and others ${ }^{12}$.

It should be noted that a number of political parties that have been represented in local authorities have chosen another electoral tactics, concentrating the forces at regional or sub-regional levels, nominating their candidates to a small number of local councils. The regional localization of such parties is related to: a) working efficiency of individual local units of the national party (the principle of functioning of a multi-level party); b) providing the participants interested in the election process with the party brand (political franchise); c) functioning of national parties in separate regions according to the principle of "regional party-electoral machines".

\section{Changing the Configuration of Ukraine's Party System Following the 2019 Presidential and Parliamentary elections}

The fourth period (begins in 2019) began with the 2019 presidential and parliamentary elections. It should also be noted that the parliamentary elections took place immediately after the presidential elections (political experts called them the "third" presidential round), and therefore the presidential campaign had a decisive influence on the result of the elections to the Verkhovna Rada of Ukraine. But if the presidential election were directed against the previous political and ruling elite, headed by P. Poroshenko, the parliamentary elections demonstrated the consolidation of Ukrainian citizens around new political ideas and trends, including the European choice of Ukraine.

The logic of the election campaign was constructed by the candidates as follows: some candidates with pro-European slogans counted on the support of the West and the Center of Ukraine, and the other part - on the East and the South. The logic was justified and provided good electoral dividends for both the pro-government and opposition political forces during 1991-2014, though the society received a regional split.

But 2019 presidential election was different from the previous one due to the fact that the electorate was oriented on a dramatic change in the Ukrainian political party. Such a demand of the electorate, being fixed in a sociological survey, coincides with the appearance of atypical, not connected with old political candidates - V. Zelensky. V. Zelensky carried out its election campaign without

12 Остапець Ю. Еволюція партійної системи України в умовах трансформації соціальних і політичних структур/ Ужгород: ЗІППО, 2016. С. 226. 
using socio-cultural messages, which divide an electorate into the East and the West (language, religion, geopolitical practice), but focus on the problems common to all the Ukrainians - stopping the war, fighting the corruption, welfare improvement. The calculation of V. Zelensky's election headquarters proved to be correct. Out-of-system character of the candidate, the emphasis on vitally important issues influenced the electoral results, and he won the first round of the elections ${ }^{13}$. Table 4 shows the results of the first round of elections for candidates who gained more than $1 \%$ of the vote. The table also shows the results of national exit polls, party affiliation / party support for candidates, the uniformity index of voting for political parties that supported candidates for the presidency in the 2014 parliamentary elections (PNS), and the uniformity index of support for candidates in the first round of presidential elections (PNS for candidates). The results of the presidential election show that the Homogeneity Index (in our case Jones - Mainwaring Nationalization Index is calculated) of regional voting for the main presidential candidates, each of them being represented by a political party, is low. Accordingly, the 2019 presidential election shows that voting for candidates was regional in nature. The only exception was V. Zelensky's candidacy, whose vote homogeneity index was the highest -0.84 .

Table 4

Results of the First Round of the Presidential Elections (2019) in Terms of Homogeneity/Heterogeneity of the Regional Voter Choice

\begin{tabular}{|c|c|c|c|c|c|}
\hline $\begin{array}{l}\text { Names of the } \\
\text { Cndidates }\end{array}$ & $\begin{array}{c}\text { Political } \\
\text { party }\end{array}$ & 完 & 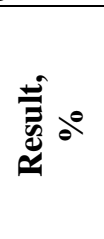 & 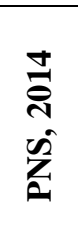 & 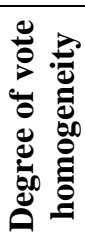 \\
\hline 1 & 2 & 3 & 4 & 5 & 6 \\
\hline Zelensky V. & $\begin{array}{l}\text { political party } \\
\text { "Sluha Narodu" } \\
\text { ("People's Servant") }\end{array}$ & 30,6 & 30,24 & - & 0,84 \\
\hline Poroshenko P. & $\begin{array}{l}\text { Political party "Bloc Petra } \\
\text { Poroshenka "Solidarnist"" } \\
\text { ("Petro Poroshenko's } \\
\text { Bloc" "Solidarity" }\end{array}$ & 17,8 & 15,95 & 0,89 & 0,77 \\
\hline Tymoshenko Yu. & $\begin{array}{l}\text { all-Ukrainian union } \\
\text { "Batjkivshchyna" } \\
\text { ("Fatherland") }\end{array}$ & 14,2 & 13,4 & 0,85 & 0,81 \\
\hline
\end{tabular}

${ }^{13}$ Рябчук М. Випробування виборами.URL.: https://zbruc.eu/node/91268 
Table 4 (continued)

\begin{tabular}{|c|c|c|c|c|c|}
\hline 1 & 2 & 3 & 4 & 5 & 6 \\
\hline Boiko Yu. & $\begin{array}{l}\text { political party } \\
\text { "Opozytsiyny bloc" } \\
\text { ("Opposition Bloc") }\end{array}$ & 9,7 & 11,67 & 0,42 & 0,55 \\
\hline Hrytsenko A. & $\begin{array}{l}\text { political party } \\
\text { "Hromadjska posytsia" } \\
\text { ("Civic Position") }\end{array}$ & 7,1 & 6,91 & 0,85 & 0,66 \\
\hline Smeshko I. & $\begin{array}{l}\text { political party } \\
\text { "Syla I Chest"" } \\
\text { ("Strength and Honor" }\end{array}$ & 6,5 & 6,04 & 0,83 & 0,79 \\
\hline Lyashko O. & $\begin{array}{l}\text { Radykalna Partia Oleha } \\
\text { Lyashka ("Oleh Lyashko's } \\
\text { Radical Party") }\end{array}$ & 4,7 & 5,48 & 0,81 & 0,74 \\
\hline Vilkul O. & $\begin{array}{l}\text { political party } \\
\text { "Opposition Bloc, } \\
\text { the Party of Peace } \\
\text { and development" }\end{array}$ & 4,0 & 4,15 & - & 0,51 \\
\hline Koshulynsky R. & $\begin{array}{l}\text { All-Ukrainian union } \\
\text { "Svoboda" }\end{array}$ & 1,7 & 1,62 & 0,75 & 0,51 \\
\hline
\end{tabular}

According to the first round results, V. Zelensky won the elections in most regions of Ukraine, except those where Yuriy Boyko (Donetsk, Luhansk oblasts), Y. Tymoshenko (Ivano-Frankivsk region), P. Poroshenko (Lviv, Ternopil regions) received the majority of votes) ${ }^{14}$. In the second round V. Zelensky won with a result of $73,22 \%$, whereas his opponent P. Poroshenko - received $24,45 \%$. V. Zelensky won the elections in all the regions of Ukraine except for Lviv.

Consequently, the following conclusions can be drawn from the election results. Firstly, "greening" (V. Zelensky's victory) does not imply reunification of Ukraine. The electorate of Ukraine remained divided at the level of identities (Eastern / Western). Its unification is possible at the expense of a prudent national policy that will take into account the requests of both the population of the East and the West of Ukraine. Secondly, the presidential election had a decisive influence on the parliamentary election campaign, outlining its format and vectors of political competition. Most presidential candidates were members of political parties, or nominated by political parties. Therefore, their participation in the elections is an opportunity to test the party brands ranking in the presidential campaign. The ratings of party brands in the presidential

\footnotetext{
${ }^{14}$ Офіційний сайт Центральної виборчої комісії. URL: http://www.cvk.gov.ua
} 
campaign are presented in Table 4. Thirdly, the election results showed that voters in the parliamentary elections would first and foremost give priority to new, non-governmental political forces.

The 2019 parliamentary elections were extraordinary since the Verkhovna Rada of Ukraine was dissolved by the Decree of the President of Ukraine V. Zelensky immediately after his inauguration on May 21, 2019, as such, where no parliamentary majority was formed. The elections were held in accordance with the law (with minor changes), adopted in November 2011, which established a mixed electoral system with election threshold of 5\% and a ban on political party blocs ${ }^{15}$.

The participants of the presidential race can be divided into the following groups: 1) the pro-presidential party "People's Servant"; 2) parliamentary political parties: "Batjkivshhyna", "Samopomich", political party "European Solidarity" (formed as a result of the re-branding of Petro Poroshenko's Bloc "Solidarity", political party "Opposition Bloc"; 3) wellknown party brands, who have repeatedly participated in election campaigns: all-Ukrainian unity "Svoboda", political party "Civic Position", Agrarian Party of Ukraine, political party "Power and Honor", "Patriot", and others; 4) new political parties that first participated in the parliamentary elections: the "Voice", the "Ukrainian Groisman's Strategy", the "Sharia's Party", "People's Power" and others ${ }^{16}$. The results of the 2019 parliamentary elections have significantly changed the configuration of Ukraine's party system at both the national and regional levels. According to the election outcome, 4 out of 5 new political parties overcame the 5 percent election threshold and entered the Parliament: "People's Servant", "Opposition Platform - For Life", "European Solidarity" and "Voice". From the original composition of the Verkhovna Rada, only "Batjkivshhyna" managed to enter the new Parliament. Therefore, the changes in the format of the system were so drastic that it could be called the "third" party system in Ukraine (the "second" was formed after the 2014 parliamentary elections, when 4 new political forces entered the Parliament).

During the parliamentary elections, the political party "People's Servant" associated with V. Zelensky, did not speculate on identity issues (European choice, recovery of historical memory, national church, etc.), which led to a uniform result throughout Ukraine (nationalization index is equivalent to 0.89 ). Political party "People's Servant" skillfully took into account the ambivalence of the Ukrainian electorate (Western / Eastern) in their pre-election rhetoric, emphasizing the importance of combating corruption, changing the old political elite, cease of the war, etc.

15 Закон України «Про вибори народних депутатів України» (17 листопада 2011 р.). URL: https://zakon.rada.gov.ua/laws/show/4061-17

${ }^{16}$ Рябчук М. Випробування виборами. URL: https://zbruc.eu/node/91268 
Thus, due to the results of the parliamentary elections the following conclusions can be made. Firstly, radical changes have taken place in the structure and configuration of the party system. The party system is represented by a system with the dominant party. The effective number of parliamentary parties decreased to 2.7 and the electoral ones to 4.4. Instead, the volatility index had the highest index during 1998-2019, which is explained by the "electoral revolution" of 2019. All the other winning parties can be called regional, which is confirmed by the calculations of the Nationalization index and the zoning of electoral support: political party the "European Solidarity", political party the "Voice" -0.58 , political party the "Batjkivshhyna" -0.77 , political party the "Opposition Platform - For Life" - 0.55.

All of them continued losing electoral support as they proceeded from the west to the east (political party "Solidarity", political party "Voice", "Batjkivshhyna", or vice versa - from east to west ("Opposition Platform - For Life", "Opposition Bloc", political party "Sharia's Party"). According to the results of the 2019 parliamentary elections the overall index of the nationalization of the party system of Ukraine is equivalent to 0.74 . This is one of the highest figures in the history of parliamentary elections in Ukraine.

The political party "People's Servant" has demonstrated an absolute record in the history of parliamentary elections, obtaining $43.16 \%$ of the votes (124 mandates) introducing 130 deputies into the majority districts. The party obtained the majority (254 MPs) in the Parliament and formed a new government, taking full responsibility for domestic and foreign policies of the state. Secondly, the political parties that succeeded in the elections were formed due to rebranding or splitting in old party structures, and therefore all of them were virtual organizations that had no organizational structures in the regions of Ukraine before the elections. Despite that, they were able to gain considerable voter support ${ }^{17}$.

The political party "People's servant" was formed due to rebranding of the "Party of Decisive Change", which was registered on April 13, 2016. The party's political ideology is libertarianism. Named after the eponymous Ukrainian comedy political series, in which a simple history teacher played by V. Zelensky became the president. Television series and feature films is considered to be one of the political technologies that has been successfully applied to win the elections. Political party "Voice" was established at the initiative of the frontman of the famous Ukrainian rock band "Ocean Eljzy" S. Vakarchuk through renaming the political party "Platform of Initiatives" on May 21, 2019. The political party is characterized by centre-right, pro-European ideology. Similarly to the political party "People's Servant", the political party

\footnotetext{
${ }^{17}$ Офіційний сайт Центральної виборчої комісії. URL: http://www.cvk.gov.ua
} 
"Voice" had no fixed party structure at the beginning of the election campaign. Political party "European Solidarity" is the political party "Petro Poroshenko's Bloc "Solidarity", renamed on May 24, 2019. The reason for the change of the name was the electoral defeat of P. Poroshenko in the presidential race and the need to change their political strategy and tactics ${ }^{18}$.

The political party "Political Platform - For Life" was formed as a result of the split in political party "Opposition Bloc", which represented the former "Party of Regions" and always consisted of two groups: "Donetsk industrialists" (R. Akhmetov, V. Novinsky) and "gas business representatives" (D. Firtash, S. Lyovochkin, Y. Bojko). The representatives of these groups could not agree to a merger, and therefore participated in the elections in the format of individual parties - political party "Opposition Bloc" and political party "Opposition Platform - For Life." In order to strengthen the positions, R. Akhmetov's group has teamed up with several regional parties: the political party "Trust in Affairs" (G. Trukhanov, G. Kernes), the political party "Renaissance" (V. Khomutinnik, E. Geller) and the "Ours" (E. Murajev) ${ }^{19}$.

In accordance with the plan of the leaders, such an association should have provided synergy and demonstrate the electorate a unified party of "successful businessmen and industrialists" in the South East. However, such an expansion of the political party "Opposition Bloc" did not add electoral potential and was not able to overcome the electoral threshold.

The political party "Ukrainian Groysman's Strategy" and political party "Sharia's party" also became the subjects to the electoral process. These parties have received significant voters support, allowing them to receive state funding. The first one was established by the Prime Minister of Ukraine V. Groysman, who decided to take part in the parliamentary elections with his own political force, and the second one is the political party of the famous pro-Russian blogger A. Sharia.

Thus, except for the all-Ukrainian unions "Batjkivshhyna" and "Svoboda", "Oleg Lyashko's Radical Party", "Opposition Bloc", the majority of the subjects of the electoral process virtually had no organizational structures in the regions; there were virtual structures that carried out agitation by means of political advertising in the media and social networks. Therefore, the election showed the increasing role of social networks in the election campaign and the tendency to "virtualize" Ukrainian parties ${ }^{20}$.

18 Фесенко В. Дневник парламентских выборов - 2019: финал. URL.: https://blogs.pravda.com.ua/authors/fesenko/

${ }^{19}$ Сухарина А. Хто, де і як голосував на виборах до Ради. URL.: https://dif.org.ua/ article/bitva-pokolin-khto-de-i-yak-golosuvav-na-viborakh-do-radi

20 Леліч М. Повз Раду: чим займуться партії та їхні лідери, що не потрапили в новий парламент. URL: https://www.rbc.ua/ukr/news/mimo-rady-zaymutsya-partii-lidery-popavshie1564863190.html 
Thirdly, political force that speculated on the threat of Russophobia, nationalism, fascism - an all-Ukrainian union "Svoboda" - received a poor rating. Despite the fact that it united 4 other nationalist parties on its platform (political parties "National Corpus", the "Congress of Ukrainian Nationalists", the "Organization of Ukrainian Nationalists", and the political party "Right Sector), its result made up only $2.15 \%$ of the vote.

Fourthly, elections in majority districts destroyed the old patron-client model of voting, when a major-deputy engaged in the improvement of the district, would provide material aid (both financial assistance and food aid), and voters would "thank" him with their votes. In our opinion, it will be practically impossible to return to this election model in the future, being one of the arguments for establishing a proportional electoral system.

\section{CONCLUSIONS}

In our opinion, the 2019 presidential and parliamentary elections can be called a "Ukrainian electoral revolution" for at least of two reasons. Firstly, as a result of the elections, there was a change of generations in the Ukrainian political elite, since young politicians aged 25-35 mostly came to power in order to change drastically the state of affairs in Ukrainian politics. Secondly, the Ukrainian citizens wanted radical changes, being the main motivating determinant for voting. The basic message of both election campaigns was the message to change the old political elite, hence, the political parties putting that idea forward and being represented in the party lists under new names received the majority of votes (political party "People's Servant" and political party "Voice").

Both the national and regional configuration of the party system of Ukraine are constituted by the following components: 1) national parliamentary political parties that have overcome the electoral threshold; 2) national nonparliamentary parties that obtained at least $2 \%$ of the votes in the elections to the Verkhovna Rada of Ukraine; 3) regional political parties represented in regional and district councils of several regions; 4) sub-regional parties: a) political parties of one / several single-mandate constituencies; local parties that situationally use local policies to provide electoral support for local government elections. High level of volatility, in comparison with relatively low value of the index of the nationalization of political parties, according to the 2019 parliamentary elections results, indicates that despite the significant changes in the structure of the party format, the heterogeneity (regionality) of party preferences in Ukrainian citizens remains high (Table 2). And the increase in the level of electoral homogeneity in the parliamentary elections of 2014 and 2019 does not yet determine the tendency to increase the level of nationalization of the party system, since the attitude towards the identity characteristics of the 
society before and during the 2019 election campaigns remained polarized along the East-West line. Thus, two tendencies in the development of Ukraine's party system can be traced: nationalization and regionalization. At different stages of the development, one of them, depending on the cumulative effect of a number of factors, becomes clearly evident.

\section{SUMMARY}

The party system is one the society subsystems being substantially affected by a number of factors, and namely: socio-political demarcation, the electoral system, the party's legal core functional group, electoral actions. As a rule, its configuration, regional activity, and structure are being changed. Hence, the consideration of traditional tendencies of party systemsdevelopment still remains one of the topical problems of domestic political science.

The paperdescribes the development of Ukrainian party system within 1991-2004, 2004-2014, 2014-2019 periods, starting with 2019. It has been concluded that two trends are clearly observed in the development of Ukraine's party system: nationalization and regionalization. Within different periods of development, one of them, being influenced by a number of factors, is more clearly manifested.

\section{REFERENCES}

1. Голосов Г. Фрагментация партийных систем: новый метод измерения и его применеие к результатам выборов российских региональных законодательных собраний (2003-2008). Электоральное пространство современной России. Политическая наука: Ежегодник 2008. М.: РОССПЭН, 2009. С. 9-27.

2. Голосов Г. Национализация партийной системы: российская специфика / Г. Голосов, В. Григорьев. Политическая наука. 2015. № 1. C. $128-156$.

3. Закон України «Про вибори народних депутатів України» (17 листопада 2011 p.). URL: https://zakon.rada.gov.ua/laws/show/4061-17

4. Лєліч М. Повз Раду: чим займуться партії та їхні лідери, що не потрапили в новий парламент. URL: https://www.rbc.ua/ukr/news/mimorady-zaymutsya-partii-lidery-popavshie-1564863190.html

5. Манайло-Приходько Р. Вплив «установчих» виборів на еволюцію партійної системиУкраїни. Гілея: науковий вісник. Збірник наукових праць. К.: «Видавництво «Гілея», 2018. Випуск 135. С. 362-367.

6. Мироненко В. «Украинский транзит» 2. Научно-аналитический вестник Института Европы РАН. 2019. № 4. С. 21-26. 
7. Остапець Ю. Еволюція партійної системи України в умовах трансформації соціальних і політичних структур. Ужгород: ЗІППО, 2016. $252 \mathrm{c}$.

8. Остапець Ю. Електоральні процеси в Україні: загальнонаціональний та регіональний виміри. Дисертація на здобуття наукового ступеня доктора політичних наук (23.00.02 - політичні інститути і процеси). Львів, 2016. 550 с. URL: http://www.lnu.edu.ua/wp-content/ uploads/2016/11/dis_ostapets.pdf

9. Офіційний сайт Центральної виборчої комісії. URL: http://www.cvk.gov.ua

10. Партійна система України до і після Майдану: зміни, тенденції розвитку, суспільні запити. Національна безпека і оборона Украйни. 2015. № 6-7. $180 \mathrm{c}$.

11. Рябчук М. Випробування виборами.URL.: https://zbruc.eu/node/ 91268

12. Сухарина А. Хто, де і як голосував на виборах до Ради. URL.: https://dif.org.ua/article/bitva-pokolin-khto-de-i-yak-golosuvav-na-viborakh-do-radi

13. Трансформація партійної системи: український досвід у європейському контексті / За ред. Ю. Якименка. Київ: Центр Разумкова, 2017. $428 \mathrm{c}$.

14. Туровский P. Национализация и регионализация партийных систем: подходы к исследованию / Р. Туровский. Полития. 2016. № 1. C. $162-180$.

15. Фесенко В. Дневник парламентских выборов - 2019: финал. URL: https://blogs.pravda.com.ua/authors/fesenko/

\section{Information about the author:} Ostapets Yu. O., Doctor of Political Science, Professor at the Department of Political Science and Public Administration, Dean of the Faculty of the Social Sciences,

Uzhgorod National University 14, Universytetska str., Uzhhorod, 88000, Ukraine 